\title{
The environmental application over nickel supported nano-structured silica
}

\author{
from agricultural biomass
}

\author{
Amira. S. Hassan ${ }^{*}$, Essam. M .Ezzo, Suzan. A. Hassan and
}

Magda. A. El kherbawi

Chemistry Department, Faculty of Women for Science, Ain Shams University, Asmaa Fahmi Street, Cairo, Egypt

\begin{abstract}
:
The objective of this study is the removal of some environmental hazards from aqueous solutions using six nickel on two supports prepared by impregnation and sol-gel methods. The first support was rice husk ash ( $\mathrm{SiR}$ ) and the other was silica-gel $\mathrm{SiG}$ by different loading weight percent of nickel 4.80, 9.60, 14.80, 4.90, 9.80 and $14.70 \%$ respectively, which were produced, Ni/SiRI, Ni/SiRII, Ni/SiRIII, Ni/SiGI, Ni/SiGII and Ni/SiGIII, respectively. The solids were described by TGA, DTA, DSC, XRD, TEM and BET measurements. The surface analyses show that for the bare $\mathrm{SiR}$ support is a common amorphous structure and in Ni/SiR catalyst precursors after calcination at $773 \mathrm{~K}$, nickel is presented as $\mathrm{NiO}$ species. TEM images depict that nickel crystallites are spherical in shape, its size is in nano-scale and much lower than $14 \mathrm{~nm}$ and distributed uniformly. The adsorption of hazard material likeCr ${ }^{+6}$ is maximal at the lowest values of $\mathrm{pH}$ and increases with temperature for the prepared solids. Optimum conditions for $\mathrm{Cr}^{+6}$ removal were found to be $\mathrm{pH}=3.00$, adsorbent dosage $0.05 \mathrm{~g} / \mathrm{L}$ of solution and equilibrium time $2.00 \mathrm{~h}$. The experimental data were analyzed using Freundlich, Langmuir and Dubinin-Radushkevich (D-R) isotherm models. It was found that Freundlich and $\mathrm{D}-\mathrm{R}$ models fitted well. The value of the adsorption energy calculated using $\mathrm{D}-\mathrm{R}$ isotherm, was $1.20 \pm 0.10 \mathrm{~kJ} / \mathrm{mol}$ for $\mathrm{Ni} / \mathrm{SiR}$ and $\mathrm{Ni} / \mathrm{SiG}$ solids and it indicated that the adsorption process was physical in nature. The $\mathrm{Ni} / \mathrm{SiG}$ solids shows higher capacity for adsorption of $\mathrm{Cr}(\mathrm{VI})$ than $\mathrm{Ni} / \mathrm{SiR}$ solids.
\end{abstract}

Key words: Rice husk ash silica ; NiO catalyst ; Nano silica support ; Impregnation method ; Sol-gel method ; Chromium hexavalent

\section{Introduction}

The need for cost-effective removal of dyes and pigments from wastewater has led to a proliferation of research into the use of low cost agro-waste adsorbent for dye removal. Dye production industries and many other industries which use pigments and dyes are increasing globally by the day with advancement in technology. Presence of pigments in wastewater constitute environmental hazard because pigments are difficult to degrade.

Corresponding author : amira.said@women.asu.edu.eg 
Pigments containing chromium, as environmental contaminant, can enter into the ecosystem fromelectroplating, chromate preparation, metal finishing, leather tanning, atomic power plants، mining, cooling towers of heavy industry, metallurgy operations etc(Khezami \& Capart, 2005). Strong exposure of $\mathrm{Cr}^{+6}$ causes cancer in the digestivetract and lungs and may cause epigastria, nausea, vomiting, severe diarrhea and hemorrhage(Huang \& Wu, 1977). It is therefore, essential toremove $\mathrm{Cr}^{+6}$ from wastewater before disposal. Numerous treatment methods such as chemical reduction, photo-catalytic reduction, ion exchange, membrane separations, chemical precipitation, electrochemical precipitation, adsorption and biosorption have been tested for chromium laden wastewater remediation in yester years(Faust \& Aly, 2013; Kadirvelu et al.,2001).Most of these technologies are quite satisfactory in terms of purging chromium from wastewater but many of these produce sludge containing important concentrations of toxic ions like $\mathrm{Cr}, \mathrm{Cu}, \mathrm{Cd}$, Pbetc whose final disposal is still a problem. The commercially available activated carbon in powder or granular form is effective for the removal of various pigments, dyes and heavy metal ions(Bansal, et al., 2009). However, due to prohibitive cost their use is limited in developing countries like Egypt. In recent years, several waste like rice husk ash (RHA) has been tested for their heavy metals and pigments removal efficiency from synthetic wastewaters. Several authors have reported the efficiency of RHA as an adsorbent for the individual removal of $\mathrm{Ni}^{+2}, \mathrm{Cd}^{+2}$ and $\mathrm{Zn}^{+2}$ from aqueous solutions(Kadirvelu et al., 2001). The present investigation is devoted to study the removal of pigment containing, $\mathrm{Cr}^{+6}$ from wastewaters by using six prepared solids of Ni/SiRI, Ni/SiRII, Ni/SiRIII, Ni/SiGI, Ni/SiGII and Ni/SiGIII. The effects of $\mathrm{pH}$, adsorbent dose, temperature, concentration of metal ions and contact time have been investigated. The data obtained may be useful for environmental hazard removal.

\section{Materials and Methods}

This study dealing with two groups of solids are I. prepared from RHA by impregnation method ,and II- prepared from TEOS by sol-gel method. In the first group ,Rice husk, was received and isolated from a rice mill that grow in Kom Hamada, Al Buhayrah, Egypt. The rice husk was washed thoroughly with distillated water in order to remove adhering soil and then it was dried in an air oven at $373 \mathrm{~K}$ for $24 \mathrm{~h}$. The dried rice husk was refluxed with $3.00 \mathrm{~N}$ $\mathrm{HNO}_{3}$ in a glass round-bottomed flask at its boiling point $373 \mathrm{~K}$ for $1.00 \mathrm{~h}$. The mixture was then filtered and washed repeatedly with warm distilled water until the filtrate was free from acid. The material was then dried at $373 \mathrm{~K}$ for $24.00 \mathrm{~h}$ and then heated in an air furnace at $1173 \mathrm{~K}$ for $1.00 \mathrm{~h}$ to remove carbon. The white rice husk ash was obtained with amorphous silica content higher than $99.00 \%$. Such ash was used as a support for catalyst preparation and designated as $\mathrm{SiR}$. The Ni catalysts supported on $\mathrm{SiR}$ were prepared by the impregnation technique .A solution of nickel nitrate of known concentrations 4.80, 9.60 and $14.80 \%$ was allowed to pass drop wise over SiRto produce Ni/SiRI, Ni/SiRII and Ni/SiRIII with constant stirring see Table(1). The products obtained were dried in an electric oven at $420 \mathrm{~K}$ for 4.00 
hour. The solid was crushed in Pyrex mortar. The desired diameter of grain size $(0.25-0.5 \mathrm{~mm})$ was chosen for adsorption measurements by using appropriate sieves and calcining at $773 \mathrm{~K}$ for $4.00 \mathrm{~h}$. The other catalysts were prepared by sol-gel method in which $\mathrm{SiO}_{2}$ sol was obtained by hydrolyzing $31.91 \mathrm{~g}$ of TEOS in mixture of $21.26 \mathrm{~g}$ of THF , $6.74 \mathrm{~g} \mathrm{of} \mathrm{H}_{2} \mathrm{O}$ and $0.75 \mathrm{~g}$ of $2.00 \mathrm{M}$ of $\mathrm{HCl}$ under magnetic stirring at $65-70^{\circ} \mathrm{C}$ for $3 \mathrm{~h}$. The $\mathrm{SiO}_{2}$ sol was then mixed with a solution of nickel nitrate with $4.90,9.80$ and $14.70 \%$ concentration to produce $\mathrm{Ni} / \mathrm{SiGI}$, $\mathrm{Ni} / \mathrm{SiGII}$ and $\mathrm{Ni} / \mathrm{SiGIII}$ respectively, was allowed to pass drop wise with constant stirring for 24.00h. Finally, the cross linking agent $\mathrm{Si}\left(\mathrm{OC}_{2} \mathrm{H}_{5}\right)_{4}$ was added to the system to form a transparent binary gel .The gel obtained was dried at room temperature for 2.00 days, ground into fine powder and then heated at $323 \mathrm{~K}$ for $5.00 \mathrm{~h}$ and calcining at $773 \mathrm{~K}$ for $4 \mathrm{~h}$. Samples of waste water of $\mathrm{Cr}^{+6}$ was received from Qaha, factory for chemical industries, Qalyoubia , Cairo, Egypt, and $\mathrm{pH}$ of thesolutions was adjusted using 0.01 M NaOH/0.01 M HCl using pHmeter (Model pHep, Hanna Instruments, calibrated with buffers. The $\mathrm{Cr}^{+6}$ concentration was determined byAtomic Absorption spectrophotometer(Shimadzu 6300, Japan).Batch experiments were carried out at different $\mathrm{pH}(3.00-9.00)$, adsorbent dose $(0.01-0.05 \mathrm{~g} / \mathrm{l})$ and stirring speed (180 rpm) for a contacttime of (30-180) min. For each batch experiment, $10 \mathrm{ml}$ solution of waste water was used.

\section{Results and Discussion}

\subsection{Effect of $\mathrm{pH}$}

ThepH of the medium has a significant effect on the sorption of metal ions on different adsorbents. This is partly due to the fact that the hydrogen ion itself is a strong competing adsorbate and partly due to the chemical speciation of metal ions under the influence of the solutionpH. At acidic $\mathrm{pH}$, the predominant species of $\mathrm{Cr}$ are $\mathrm{Cr}_{2} \mathrm{O}_{7}^{-2}, \mathrm{HCrO}_{4}{ }^{-1}, \mathrm{H}_{2} \mathrm{CrO}_{4}$, $\mathrm{Cr}_{3} \mathrm{O}_{10}{ }^{-2}$ and $\mathrm{Cr}_{4} \mathrm{O}_{13}{ }^{-2}$. The adsorption of metal ions depends upon the nature of the adsorbent surface and the species distribution of the metal ions in the aqueous solution.

\begin{tabular}{|c|c|c|c|c|c|c|}
\hline Samples & $\begin{array}{c}\text { Silica } \\
\text { Source }\end{array}$ & $\begin{array}{c}\text { Chemical } \\
\text { Composition } \\
\text { of } \mathrm{Ni} \%\end{array}$ & $\begin{array}{c}\text { True chemical } \\
\text { Composition by } \\
\text { A.A. of Ni \% }\end{array}$ & $\begin{array}{c}\text { Specific surface } \\
\text { area }, \\
m^{2} \cdot g^{-1}\end{array}$ & $\begin{array}{c}\text { Method of } \\
\text { Preparation }\end{array}$ & $\begin{array}{c}\text { Calcinations } \\
\text { Temp., } \\
\text { K }\end{array}$ \\
\hline $\mathrm{Ni} / \mathrm{SiRI}$ & \multirow{3}{*}{ RHA } & 5.00 & 4.80 & 48.70 & \multirow{3}{*}{ Impregnation } & \multirow{3}{*}{773} \\
\hline $\mathrm{Ni} / \mathrm{SiRII}$ & & 10.00 & 9.60 & 70.35 & & \\
\hline $\mathrm{Ni} / \mathrm{SiRIII}$ & & 15.00 & 14.80 & 125.00 & & \\
\hline $\mathrm{Ni} / \mathrm{SiGI}$ & \multirow{3}{*}{ TEOS } & 5.00 & 4.90 & 335.00 & \multirow{3}{*}{ Sol. gel. } & \multirow{3}{*}{773} \\
\hline $\mathrm{Ni} / \mathrm{SiGII}$ & & 10.00 & 9.80 & 274.00 & & \\
\hline $\mathrm{Ni} / \mathrm{SiGIII}$ & & 15.00 & 14.70 & 202.00 & & \\
\hline
\end{tabular}


The effect of $\mathrm{pH}$ on the removal of $\mathrm{Cr}^{+6}$ is investigate by testing three values of $\mathrm{pH}=3.00$, 6.00 and 9.00 at room temperature for the tested wastewater $(10.00 \mathrm{mg} / \mathrm{l})$ over $0.01 \mathrm{~g} / \mathrm{l}$ for all the prepared solids. The contact time has been fixed to $1.00 \mathrm{~h}$ for all the experiments. The results presented in Fig.(1) indicate that $\mathrm{Cr}^{+6}$ removal is considerably affected by the $\mathrm{pH}$. The maximum adsorption of $\mathrm{Cr}^{+6}$ pigmentwas observed at $\mathrm{pH}$ equal 3.00 for all prepared solids. At initial $\mathrm{pH}$ of 3.00 , the adsorbent surfaces might be highly protonated which favor the uptake $\mathrm{Cr}^{+6}$ in the predominant anionic form(Dakikyet al., 2002; Raoet al., 1992). With increase in $\mathrm{pH}$, the degree of protonation of the surface reduces and hence adsorption is decreased. Furthermore, as $\mathrm{pH}$ increases, there is competition between $\mathrm{OH}^{-}$and chromate ions. Hence, adsorption of $\mathrm{Cr}^{+6}$ on the adsorbent was not significant at greater $\mathrm{pH}$ values due to dual competition of both the anions $\left(\mathrm{CrO}_{4}{ }^{2-}\right.$ and $\left.\mathrm{OH}^{-}\right)$to be adsorbed on the surface of the adsorbent of which $\mathrm{OH}^{-}$predominant. Maximum adsorption occurs at $\mathrm{pH} 3.00$ and hence it was taken as the optimal value for further adsorption studies for all solids. Generally for all the prepared $\mathrm{Ni} / \mathrm{SiRI}, \mathrm{Ni} / \mathrm{SiRII}, \mathrm{Ni} / \mathrm{SiRIII}, \mathrm{Ni} / \mathrm{SiGI}, \mathrm{Ni} / \mathrm{SiGII}$ and Ni/SiGIII solids by increasing of $\mathrm{Ni}$ content, the removal of the pigments increase.
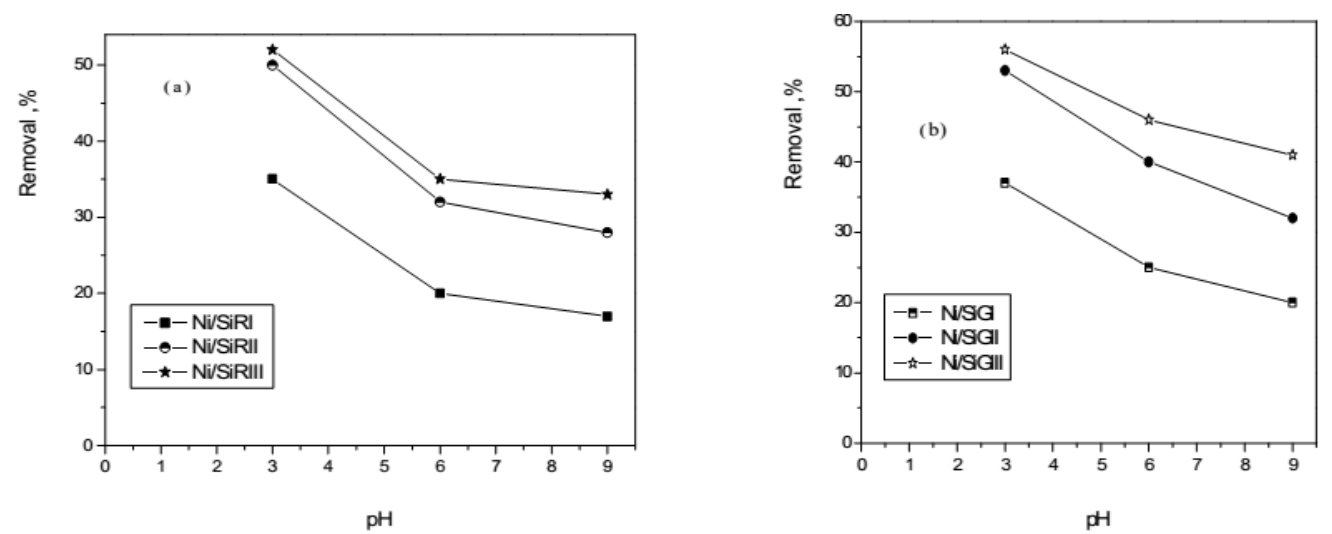

Fig.(1) : Effect of $\mathrm{pH}$ on the adsorption of $\mathrm{Cr}(\mathrm{IV})$ from waste water onto a) $\mathrm{Ni} / \mathrm{SiR}$ andb) Ni /SiG solids.

\subsection{Effect of adsorbent dose}

The removal of metal ions is a function of adsorbent dosage, so the efficiency of the prepared solids was evaluated at different adsorbent doses for the percent removal of chromium. The experiments were conducted at constant initial concentration $=10.00 \mathrm{mg} / \mathrm{l}$, contact time $=1.00$ $\mathrm{h}, \mathrm{pH}=3.00$, at room temperature and stirring speed $=180 \mathrm{rpm}$ with varying adsorbent doses $0.01-0.05 \mathrm{~g} / 1$. Measurement of percentage $\mathrm{Cr}^{+6}$ removal as a function of time at different doses indicates that removal of $\mathrm{Cr}^{+6}$ increased with increasing adsorbent dose (Fig.(2)). Increase in $\mathrm{Cr}^{+6}$ removal with adsorbent dose can be attributed to increased $\mathrm{S}_{\mathrm{BET}}$ and the availability of more adsorption sites (Kadirvelu et al., 2000)for all the prepared solids. 

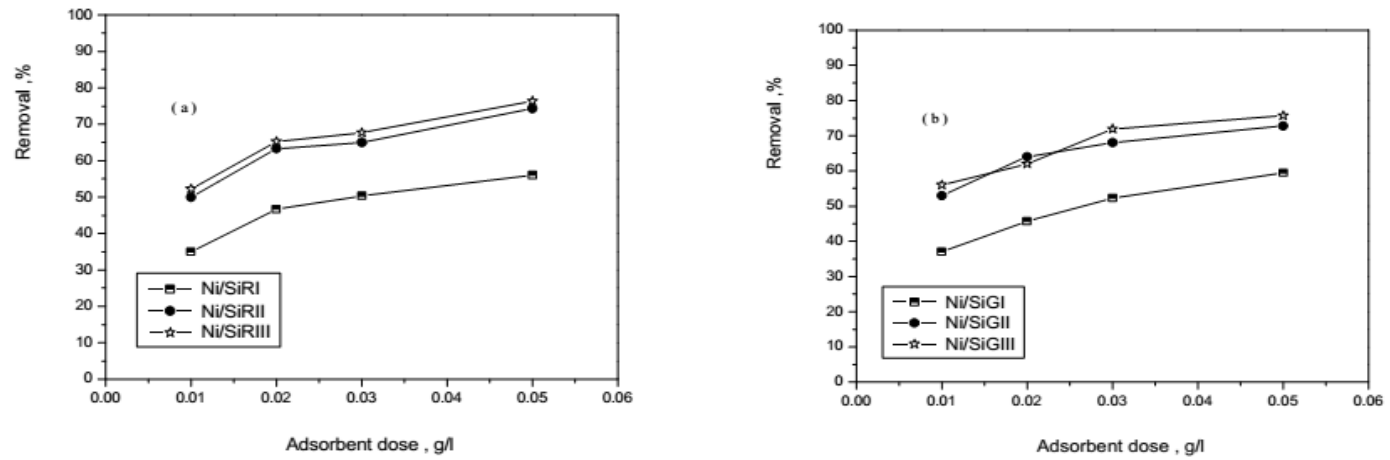

Fig.(2) : Effect of adsorbent dose on the adsorption of Cr(IV) from waste water onto

a) $\mathrm{Ni} / \mathrm{SiR}$ andb) $\mathrm{Ni} / \mathrm{SiG}$ solids.

\subsection{Effect of contact time}

The effect of changing the contact time on adsorption, while keeping the adsorbent dose $=0.01 \mathrm{~g} / \mathrm{l}, \mathrm{pH}=3.00$ and stirring speed $=180 \mathrm{rpm}$ constant at room temperature illustrated in Fig (3).The removal of $\mathrm{Cr}^{+6}$ has increased with time and attains a maximum value at about $120 \mathrm{~min}$ and reached to $60.43,75.97,77.66,62.77,78.52$ and $81.67 \%$ for Ni/SiRI, Ni/SiRII, $\mathrm{Ni} / \mathrm{SiRIII}, \mathrm{Ni} / \mathrm{SiGI}, \mathrm{Ni} / \mathrm{SiGII}$ and $\mathrm{Ni} / \mathrm{SiGIII}$ solids respectively and thereafter, it remains almost constant. This may be due to the fact that as the pigment solution-adsorbent system is being agitated at longer time, more of the molecules or atoms of the pigment tend to accumulate on the surface of the adsorbent until equilibrium is reached.
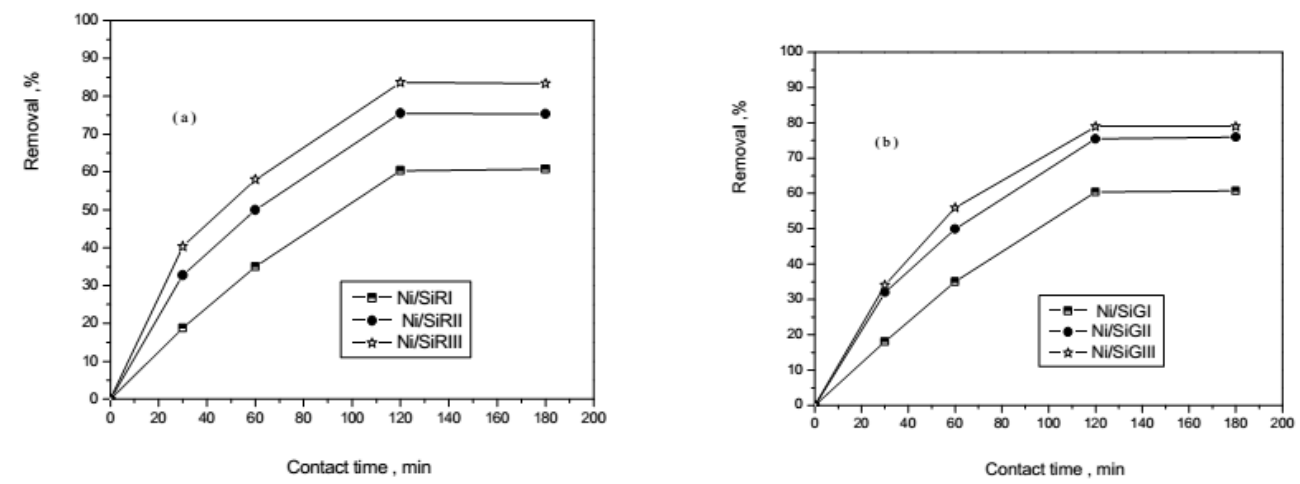

Fig.(3) : Effect of contact time on the adsorption of $\mathrm{Cr}(\mathrm{IV})$ from waste water onto a) $\mathrm{Ni} / \mathrm{SiR}$ and b) $\mathrm{Ni} / \mathrm{SiG}$ solids.

\subsection{Effect of temperature}

An increase in temperature is known to increase the diffusion rate of the adsorbate molecules across the external boundary layer and within the pores. This could be the result of decreasing the viscosity of the solution. Moreover, changing the temperature will modify the equilibrium capacity of the solids for a particular adsorbate(Ho et al., 2001). The effect of temperature is investigated from adsorption tests carried out at three constant temperatures: 
300,308 and $313 \mathrm{~K}$ for $1.00 \mathrm{~h}$, the adsorbent dose $=0.01 \mathrm{~g} / 1, \mathrm{pH}=3.00$ and stirring speed $=180 \mathrm{rpm}$. The removal of $\mathrm{Cr}^{+6}$ has increased with temperature and attains a maximum value at about $323 \mathrm{~K}$ and reached to $76.06,91.69,93.87,76.06,95.93$ and $98.00 \%$ for Ni/SiRI, $\mathrm{Ni} / \mathrm{SiRII}, \mathrm{Ni} / \mathrm{SiRIII}, \mathrm{Ni} / \mathrm{SiGI}, \mathrm{Ni} / \mathrm{SiGII}$ and $\mathrm{Ni} / \mathrm{SiGIII}$ solids respectively
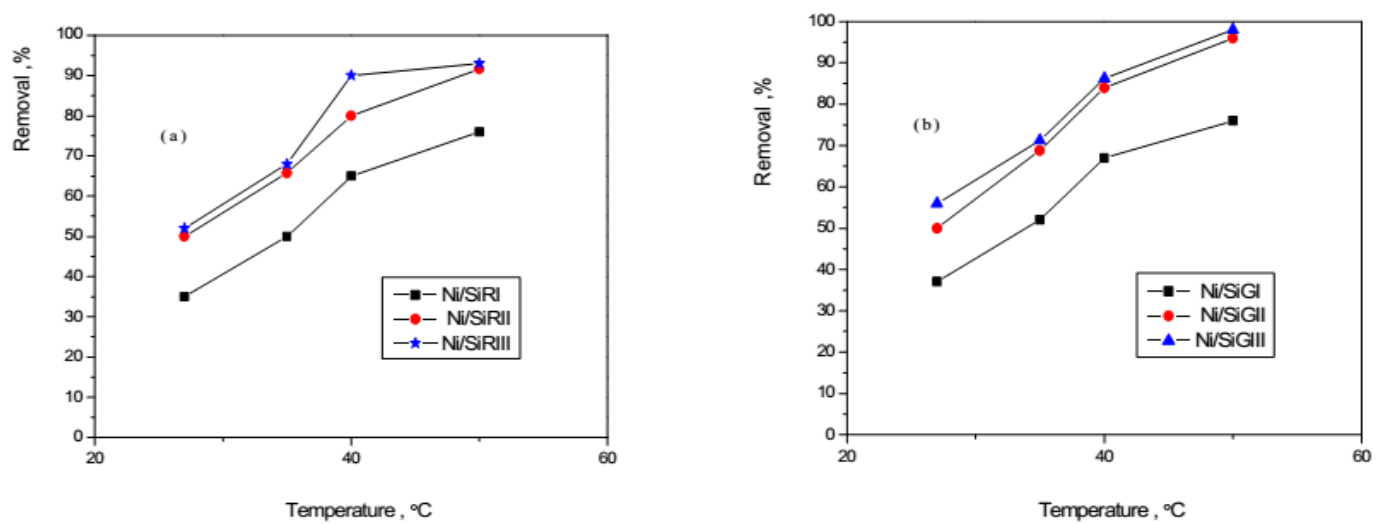

Fig.(4) : Effect of temperature on the adsorption of $\mathrm{Cr}(\mathrm{IV})$ from waste water onto

a) $\mathrm{Ni} / \mathrm{SiR}$ and b) $\mathrm{Ni} / \mathrm{SiG}$ solids.

\subsection{Effect of initial concentration}

At time $120 \mathrm{~min}$, initial metal concentration10.00, 20.00, $50.00 \mathrm{mg} / \mathrm{l}, \mathrm{pH}=3.00$, stirring speed $=180 \mathrm{rpm}$ at room temperature and adsorbent weight $0.01 \mathrm{~g}$. Table(2) showed the equilibrium absorbance $\left(\mathrm{q}_{\mathrm{e}}\right)$ and \% of removal of pigment on the prepared adsorbents. From Table (2), it is evident that the percent of heavy metals ions removal decreased when $C_{i}$ increased although the actual amount of metal ions adsorbed per unit mass of adsorbents similar observation was reported by Kumar et al (2010). The results shows that $\mathrm{Cr}^{+6}$ pigment removal is not upto the permissible disposal limit as prescribed by National Standards. But as the removal of $\mathrm{Cr}^{+6}$ pigment is dependent on $\mathrm{pH}, \mathrm{C}_{\mathrm{i}}$, temperature and adsorbent dose, so when $\mathrm{C}_{\mathrm{i}}$ is low, adsorbent dose is higher and $\mathrm{pH}$ is optimum, then the permissible levels of $\mathrm{Cr}^{+6}$ pigment can be achieved in the effluents. At low concentration, the ratio of available surface to the initial $\mathrm{Cr}^{+6}$ concentration is larger, so the removal is higher. However, for higher concentrations this ratio is low, hence the removal, percentage is also lesser. Increasing metal ion concentration decreased $\%$ of $\mathrm{Cr}^{+6}$ removal And reached to 30.98, 50.87,55.77,39.98, 57.56 and 60.00 for Ni/SiRI, Ni/SiRII, Ni/SiRIII, Ni/SiGI, Ni/SiGII and Ni/SiGIII. This could be attributed to increased rate of mass transfer due to increased concentration of driving force.

\subsection{Adsorption isotherms}

The Freundlich, Langmuir and Dubinin-Radushkevich (D-R) models have been employed as adsorption isotherm models. These isotherms relate the amount of solute adsorbed at equilibrium per unit weight of adsorbent to the adsorbate concentration at equilibrium, $\mathrm{C}_{\mathrm{e}}, \mathrm{mg} / \mathrm{l}$. The Freundlich isotherm model proposes a monolayer sorption with a heterogeneous energetic distribution of active sites, accompanied by interaction between adsorbed molecules. The general form of this model is presented as: 


$$
q_{e}=K_{f} C_{e}{ }^{1 / n}
$$

Where, $\mathrm{K}_{\mathrm{f}}$ stands for adsorption capacity, $\mathrm{n}$ for adsorption intensity, $\mathrm{q}_{\mathrm{e}}$ is the amount of $\mathrm{Cr}^{+6}$ adsorbed at equilibrium, $\mathrm{mg} / \mathrm{l}, \mathrm{C}_{\mathrm{e}}$ is the residual concentration of $\mathrm{Cr}^{+6}$ in solution, $\mathrm{mg} / \mathrm{l}$.

Table (2): Results for equilibrium parameters for the adsorption of Cr(IV) from waste water onto the prepared solids.

\begin{tabular}{|c|c|c|c|c|c|c|c|c|c|}
\hline Solids & $\begin{array}{c}C_{i} \\
m g / l\end{array}$ & $\begin{array}{c}\text { Removal., } \\
\%\end{array}$ & $\begin{array}{c}q_{0} \\
m g / g\end{array}$ & $\begin{array}{c}C_{o} \\
m g / l\end{array}$ & $\log q_{e}$ & $\log C_{e}$ & $\log \left(1+1 / C_{e}\right)$ & $1 / C_{e}$ & $C_{d} / q_{e}$ \\
\hline \multirow{3}{*}{ Ni/ SiRI } & 10.00 & 60.43 & 6.04 & 3.95 & 0.78 & 0.59 & 0.09 & 0.25 & 0.65 \\
\hline & 20.00 & 54.98 & 10.99 & 9.00 & 1.04 & 0.95 & 0.04 & 0.11 & 0.81 \\
\hline & 50.00 & 30.98 & 15.49 & 34.51 & 1.19 & 1.53 & 0.01 & 0.02 & 2.22 \\
\hline \multirow{3}{*}{ Ni/SiRII } & 10.00 & 75.52 & 7.55 & 2.44 & 0.87 & 0.38 & 0.14 & 0.40 & 0.32 \\
\hline & 20.00 & 68.00 & 13.60 & 6.40 & 1.13 & 0.80 & 0.06 & 0.15 & 0.47 \\
\hline & 50.00 & 50.87 & 25.43 & 24.56 & 1.40 & 1.39 & 0.01 & 0.04 & 0.96 \\
\hline \multirow{3}{*}{ Ni/SiRIII } & 10.00 & 77.66 & 7.76 & 2.23 & 0.89 & 0.34 & 0.16 & 0.44 & 0.28 \\
\hline & 20.00 & 70.56 & 14.11 & 5.88 & 1.14 & 0.76 & 0.06 & 0.17 & 0.41 \\
\hline & 50.00 & 55.77 & 27.88 & 22.11 & 1.44 & 1.34 & 0.01 & 0.04 & 0.79 \\
\hline \multirow{3}{*}{ Ni/SiGI } & 10.00 & 62.77 & 6.27 & 3.72 & 0.79 & 0.57 & 0.10 & 0.26 & 0.59 \\
\hline & 20.00 & 60.0 & 12.00 & 8.00 & 1.07 & 0.90 & 0.05 & 0.12 & 0.66 \\
\hline & 50.00 & 39.98 & 19.99 & 30.01 & 1.30 & 1.47 & 0.01 & 0.03 & 1.50 \\
\hline \multirow{3}{*}{$\mathrm{Ni} / \mathrm{SiGII}$} & 10.00 & 78.52 & 7.85 & 2.14 & 0.89 & 0.33 & 0.16 & 0.46 & 0.27 \\
\hline & 20.00 & 75.09 & 15.01 & 4.98 & 1.17 & 0.69 & 0.07 & 0.20 & 0.33 \\
\hline & 50.00 & 57.56 & 28.78 & 21.22 & 1.45 & 1.32 & 0.02 & 0.04 & $\begin{array}{l}0.73 \\
\end{array}$ \\
\hline \multirow{3}{*}{$\mathrm{Ni} / \mathrm{SiGIII}$} & 10.00 & 81.60 & 8.16 & 1.84 & 0.91 & 0.26 & 0.18 & 0.54 & 0.22 \\
\hline & 20.00 & 78.00 & 15.6 & 4.40 & 1.19 & 0.64 & 0.08 & 0.22 & 0.28 \\
\hline & 50.00 & 60.00 & 30.00 & 20.00 & 1.47 & 1.30 & 0.02 & 0.05 & 0.66 \\
\hline
\end{tabular}

The values of $n$ and $K_{f}$ were obtained from the intercept and slope of a plot of $\log _{\mathrm{e}}$ versus $\log C_{e}$ from linear form of Freundlich. The Langmuir isotherm model was applied to estimate the adsorption capacity of adsorbents used and suggests that uptake occurs on a homogeneous surface by monolayer sorption without interaction between adsorbed molecules. The linear form of the Langmuir adsorption isotherm is represented as:

$$
C_{e} / q_{e}=\left(1 / b Q_{o}+C_{e} / Q_{o}\right)
$$

$\mathrm{Q}_{\mathrm{o}}$, $\mathrm{mg} / \mathrm{g}$ and $\mathrm{b}, 1 / \mathrm{mg}$ are Langmuir constants related to adsorption capacity and rate of adsorption, respectively. The values of $\mathrm{Q}_{\mathrm{o}}$ and $\mathrm{b}$ were calculated from the slope and intercept of the Langmuir plot of $\mathrm{C}_{\mathrm{e}}$ versus $\mathrm{C}_{\mathrm{e}} / \mathrm{q}_{\mathrm{e}}$. Results of the modeling of the isotherms of $\mathrm{Cr}^{+}$ sorption by the prepared adsorbents according to Langmuir and Freundlichmodels, are summarized in Table (3). According to the coefficient of correlation obtained, we deducted that the model of Langmuir correlated the experimental data well and better than the Freundlich model for both the adsorbents group. From Table (3) for Ni/SiR and/or Ni/SiG solids presents the estimated parameters of Langmuir and Freundlich isotherm models for the adsorption of the $\mathrm{Cr}^{+}$ions. According to the Langmuir model, the maximum adsorption occurs when a saturated monolayer of metal ions is reached on both the adsorbents group surface and 
the energy of adsorption is constant and no migration of adsorbate molecules on the plane surface of the solids are observed.The constant $b$ in the Langmuir equation relates to the energy or the net enthalpy of the adsorption process. The higher the value of the constant $b$, the lower the free energy and the process is more favorable because it requires less energy to sustain. The Freundlich isotherm model encompasses on the surface heterogeneity and the exponential distribution of active adsorption sites and their energies . Parameter, $\mathrm{n}$ is indicative of intensity of the interaction between the adsorbent -adsorbate, showing how strong the metal ions are attached to adsorbent surface. Table (3)represents the $n$ values between 1.00 and 10.00 for $\mathrm{Ni} / \mathrm{SiR}$ and/or $\mathrm{Ni} / \mathrm{SiG}$ adsorbents, which indicate favorable adsorption process and the adsorption intensity was favorable. From the results, it is clear that the value of adsorption efficiency $\mathrm{Q}_{\mathrm{o}}$ of $\mathrm{Ni} / \mathrm{SiR}$ and /or $\mathrm{Ni} / \mathrm{SiG}$ increased by addition of $\mathrm{Ni}$ for adsorption of ions. The observed $b$ value show the endothermic nature of the process involved in the system and values of $\mathrm{n}$ are greater than one, indicating also the adsorption is much more favorable.

Table (3) :Freundlich, Langmuir and D-R models for the prepared solids.

\begin{tabular}{|c|c|c|c|c|c|c|c|c|c|c|c|}
\hline \multirow{2}{*}{ Solids } & \multicolumn{3}{|c|}{$\begin{array}{l}\text { Freundlich } \\
\text { model }\end{array}$} & \multicolumn{3}{|c|}{$\begin{array}{c}\text { Langmuir } \\
\text { model }\end{array}$} & \multirow[b]{2}{*}{$R_{L}$} & \multicolumn{3}{|c|}{$\begin{array}{c}D-R \\
\text { model }\end{array}$} & \multirow{2}{*}{$\begin{array}{c}E_{a}, \\
k J . m o l^{1}\end{array}$} \\
\hline & $\begin{array}{c}k_{f}, \\
m g \cdot g^{-1}\end{array}$ & $n$ & $R^{2}$ & $\underset{M g \cdot g^{-1}}{\boldsymbol{Q}_{o}}$ & $\begin{array}{c}b, \\
l . m g^{-1}\end{array}$ & $R^{2}$ & & $\begin{array}{c}q_{D}, \\
m g \cdot g^{-1}\end{array}$ & $\begin{array}{c}B_{D}, \\
\mathrm{~mol}^{2} \cdot k \mathrm{~J}^{2}\end{array}$ & $R^{2}$ & \\
\hline$N i / S i R I$ & 3.71 & 2.43 & 0.83 & 18.99 & 0.13 & 0.99 & 0.99 & 17.49 & 0.41 & 0.99 & 1.10 \\
\hline $\mathrm{Ni} / \mathrm{SiRII}$ & 4.26 & 1.92 & 0.99 & 35.29 & 0.10 & 0.99 & 0.99 & 13.84 & 0.32 & 0.95 & 1.25 \\
\hline $\mathrm{Ni} / \mathrm{SiRIII}$ & 5.12 & 1.85 & 0.99 & 40.04 & 0.10 & 0.99 & 0.99 & 26.60 & 0.28 & 0.88 & 1.33 \\
\hline $\mathrm{Ni} / \mathrm{SiGI}$ & 3.23 & 1.85 & 0.91 & 27.95 & 0.08 & 0.99 & 0.99 & 22.66 & 0.45 & 0.99 & 1.05 \\
\hline Ni/SiGII & 5.37 & 1.81 & 0.95 & 41.16 & 0.11 & 0.99 & 0.99 & 31.22 & 0.31 & 0.94 & 1.27 \\
\hline Ni/SiGIII & 6.30 & 1.92 & 0.95 & 41.20 & 0.13 & 0.99 & 0.99 & 32.35 & 0.27 & 0.95 & 1.36 \\
\hline
\end{tabular}

The essential characteristics of Langmuir isotherm can be expressed in terms of dimensionless constant separation factor for equilibrium parameter, $\mathrm{R}_{\mathrm{L}}$ which is defined as given below:

$$
\mathbf{R}_{\mathrm{L}}=\mathbf{1} /\left(\mathbf{1}+\mathrm{bC}_{\mathbf{0}}\right)
$$

Thus, $\mathrm{R}_{\mathrm{L}}$ is a positive number whose magnitude determines the feasibility of the adsorption process. The shape of the isotherms can be predicted by the $\mathrm{R}_{\mathrm{L}}$ value. The $\mathrm{R}_{\mathrm{L}}$ value between 0 and 1 indicates favorable adsorption of $\mathrm{Cr}^{+6}$ onto studied adsorbents. The values of $\mathrm{R}_{\mathrm{L}}$ for the studied system at different initial concentrations were found to be in between 0 and 1 which indicate favorable adsorption of $\mathrm{Cr}^{+6}$ onto the adsorbents. Langmuir model represents the monolayer adsorption on to a homogeneous surface with a finite number of active sites where as D-R model does not assume homogeneous surface. The D-R adsorption isotherm is represented as:

\section{$\log q_{e}=\log q_{D}-2 B_{D} R^{2} T^{2} \log \left(1+1 / C_{e}\right)$}


Where, $q_{D}$ is theoretical saturation capacity, $m g \cdot g^{-1} \cdot B_{D}$ is a constant related to adsorption energy $, \mathrm{mol}^{2} \mathrm{~kJ}^{-2}, \mathrm{R}$ is the gas constant and $\mathrm{T}$ is the temperature, $\mathrm{K}$. The slope of the plot log $\mathrm{q}_{\mathrm{e}}$ versus $\log \left(1+1 / \mathrm{C}_{\mathrm{e}}\right)$ gives the $\mathrm{q}_{\mathrm{D}}$ and $\mathrm{B}_{\mathrm{D}}$ values. The values of linear regression coefficient $\left(R^{2}\right)$ are in the range of $0.99-0.88$, revealing that the experimental data fitted well with the D$\mathrm{R}$ isotherm model. It is revealed that the $\mathrm{q}_{\mathrm{D}}$ values are not complying with the previously determined Langmuir isotherm $\mathrm{Q}_{0}$ values. The constant $\mathrm{B}_{\mathrm{D}}$ gives an idea about the mean free energy $E_{D}(\mathrm{~kJ} / \mathrm{mol})$ of adsorption per molecule of the adsorbate when it is transferred to the surface of the solid from infinity in the solution and can be calculated from the $\mathrm{D}-\mathrm{R}$ isotherm constant $\mathrm{B}_{\mathrm{D}}$ using following equation:

$$
E_{D}=1 /\left(2 B_{D}\right)^{0.5}
$$

The results so obtained are given in Table (3). The calculated $E_{D}$ values were found to be $1.20 \pm 0.10 \mathrm{~kJ} / \mathrm{mol}$ for $\mathrm{Ni} / \mathrm{SiR}$ and/ or $\mathrm{Ni} / \mathrm{SiG}$ solids. $\mathrm{E}_{\mathrm{D}}$ value less than $8.00 \mathrm{~kJ} / \mathrm{mol}$ as indicated by our results shows that the adsorption process of $\mathrm{Cr}^{+6}$ on the both adsorbent groups follows physical adsorption(Hasany\& Chaudhary, 1996). In contrast, if the value of $E_{\mathrm{D}}$ is located in the range of $8.00-16.00 \mathrm{~kJ} / \mathrm{mol}$, it is the chemical adsorption.

\section{Conclusions}

- $\mathrm{Ni} / \mathrm{SiR}$ and $\mathrm{Ni} / \mathrm{SiG}$ could be suitable adsorbents for the removal ofCr(VI) from waste waters. The adsorption was found to bestrongly dependent on $\mathrm{pH}$, adsorbent dose, contact time, temperature and initial $\mathrm{Cr}(\mathrm{VI})$ concentration.

- Optimum conditions for $\mathrm{Cr}^{+6}$ removal were found to be $\mathrm{pH}=3.00$, adsorbent dosage $0.05 \mathrm{~g} / \mathrm{L}$ of solution and equilibrium time $2.00 \mathrm{~h}$. The experimental data were analyzed using Freundlich, Langmuir and Dubinin-Radushkevich (D-R) isotherm models. It was found that Freundlich and D-R models fitted well.

- The $\mathrm{n}$ values between 1.00 and 10.00 for $\mathrm{Ni} / \mathrm{SiR}$ and/or $\mathrm{Ni} / \mathrm{SiG}$ adsorbents, which indicate favorable adsorption process and the adsorption intensity was favorable, and the value of adsorption efficiency $\mathrm{Q}_{0}$ of $\mathrm{Ni} / \mathrm{SiR}$ and /or $\mathrm{Ni} / \mathrm{SiG}$ increased by addition of $\mathrm{Ni}$ for adsorption of ions. The observed $b$ value show the endothermic nature of the process involved in the system and values of $\mathrm{n}$ are greater than one, indicating also the adsorption is much more favorable.

- The value of the adsorption energy calculated using D-R isotherm, was $1.20 \pm 0.10 \mathrm{~kJ} / \mathrm{mol}$ for $\mathrm{Ni} / \mathrm{SiR}$ and $\mathrm{Ni} / \mathrm{SiG}$ solids and it indicated that the adsorption process was physical in nature. The Ni/SiG solids shows higher capacity for adsorption of $\mathrm{Cr}(\mathrm{VI})$ than $\mathrm{Ni} / \mathrm{SiR}$ solids.

- Application study was also carried out to find the suitability of the process in waste water treatment operation. 


\section{References}

Bansal, M., Garg, U., Singh, D., \& Garg, V. , Removal of Cr (VI) from aqueous solutions using pre-consumer processing agricultural waste: A case study of rice husk. Journal of Hazardous Materials, 162(1), (2009), 312-320.

Dakiky, M., Khamis, M., Manassra, A., \& Mer'Eb, M., Selective adsorption of chromium (VI) in industrial wastewater using low-cost abundantly available adsorbents. Advances in environmental research, 6(4), (2002), 533-540.

Faust, S. D., \& Aly, O. M.,Adsorption processes for water treatment: Elsevier(2013).

Hasany, S. M., \& Chaudhary, M. H., Sorption potential of Haro river sand for the removal of antimony from acidic aqueous solution. Applied Radiation and Isotopes, 47(4), (1996), 467471.

Ho, Y.-S., Chiang, C.-C., \& Hsu, Y.-C., Sorption kinetics for dye removal from aqueous solution using activated clay. Separation Science and Technology, 36(11), (2001), 2473-2488.

Huang, C., \& Wu, M.,The removal of chromium (VI) from dilute aqueous solution by activated carbon. Water Research, 11(8), (1977),673-679.

Kadirvelu, K., Faur-Brasquet, C., \& Cloirec, P. L., Removal of Cu (II), Pb (II), and Ni (II) by adsorption onto activated carbon cloths. Langmuir, 16(22), (2000),8404-8409.

Kadirvelu, K., Thamaraiselvi, K., \& Namasivayam, C., Removal of heavy metals from industrial wastewaters by adsorption onto activated carbon prepared from an agricultural solid waste. Bioresource technology, 76(1), (2001),63-65.

Khezami, L., \& Capart, R., Removal of chromium (VI) from aqueous solution by activated carbons: kinetic and equilibrium studies. Journal of Hazardous Materials, 123(1-3), (2005),223-231.

Rao, P. S., Mise, S. R., \& Manjunatha, G., Kinetic studies on adsorption of chromium by coconut shell carbons from synthetic effluents. Journal of Environmental Science \& Health Part A, 27(8), (1992), 2227-2241. 


\section{الملخص باللغة العربية}

التطبيق البيئي علي النيكل المحمل علي الناتو سيليكا المحضرمن المخلفات الزراعية

أميرة سعيد حسن ، عصام محمد عزو، سوزان أحمد حسن ، ماجده عبد الباسط الخرباوي قسم الكيمياء ـ كلية البنات - جامعة عين شمس

$$
\text { تتلخص التقاط الرئيسية التي قام بها البحث على التحو التالي: }
$$

• تم تحضير ست عينات من السليكا و المحملة بالنيكل بنسب مختلفة. و قد تم تخضير السليكا النشطة من قثور الارز و ثناث عينات الاخري من السيلكا جل المحضره من الاثيل اوكسي سليكات بطريقة الصول

كتطبيق بيئي تمت در اسة تقييم كفاءة المو اد الصلبة المحضره في إزالة صبغة الكروم سداسي التكافؤ من

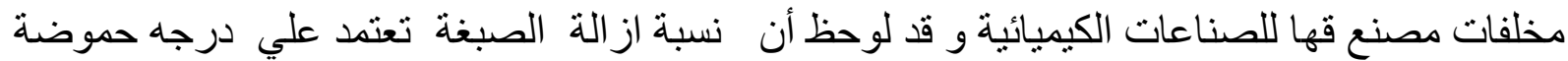

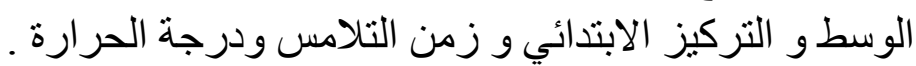
• تم حساب طاقة التنثيط لامتزاز الصبغة علي سطح المواد الصلبة المحضره ووجد انها تساوي

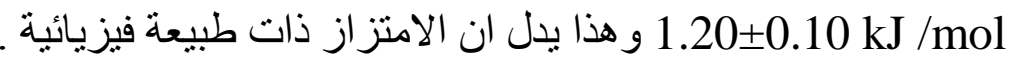

